\title{
TUHAN DALAM PERDEBATAN EKSISTENSIALISME
}

Chafid Wahyudi Abstract: The philosophy of existentialism pays hfz_why@yahoo.co.id great attention to the fate of human beings as individualist embodiments. This also becomes a manifestation of human's freedom which receives less attention due to its exclusion under the strong influence of Hegel's doctrine essentialist philosophy or system of thought that emphasizes collectivity. The emergence of existentialism itself in turn

Sekolah Tinggi Agama Islam al-Fithroh, Surabaya propagates into the polemical invention of humans upon their God. There are two conceptions of the divine discourses on existentialism, namely the theistic existentialism and the atheistic one. Theistic existentialism tries to accept God and consider Him not to rob humans' freedom because God is understood individually, not as a self-enclosed system. On the contrary, atheistic existentialism actually rebels against God's intervention in humans' freedom as well as eliminates the existence of God and brings the absolute freedom of human beings themselves, which in turn this leads to humans' creative activity.

Keywords: Existensialism, theistic, atheistic, freedom. 


\section{Pendahuluan}

Wilhelm Schmidt dalam The origin of the idea of God, yang diterbitkan pertama kali pada 1912 sebagaimana dilansir Karen Amrstrong mengungkapkan, pada mulanya, manusia menciptakan satu Tuhan yang merupakan Penyebab Pertama bagi segala sesuatu dan Penguasa langit dan bumi. Dia tidak terwakili oleh gambaran apa pun dan tidak memiliki kuil atau pendeta yang mengabdi kepadanya. Dia terlalu luhur untuk ibadah manusia yang tak memadai. Perlahan-lahan dia memudar dari kesadaran umatnya. Dia telah begitu jauh sehingga mereka memutuskan bahwa mereka tidak lagi menginginkannya. Pada akhirnya dikatakan telah menghilang. ${ }^{1}$

Seiring dengan perjalanan sejarah kemanusiaan, khususnya di Barat-Kristen yang ditandai dengan adanya revolusi ilmu (scientific revolution), yakni cerita agung tentang rasionalitas yang mulanya dihadirkan Rene Descartes (1596-1649) melalui formulasi sebuah prinsip, cogito ergo sum (aku berfikir, karena itu aku ada). ${ }^{2}$ Dengan prinsip ini, Descartes telah menjadikan rasio satu-satunya kriteria untuk mengukur kebenaran. Formulasi Descartes ini pula yang menjadi titik awal untuk mengantarkan perkembangan ilmu pengetahuan modern yang kerap disebut Pencerahan (Aufklärung).

Babakan era Pencerahan itu pada gilirannya merefleksikan abad pertengahan yang bercorak teosentris bergeser dan berubah ke antroposentris. Dalam bahasa Martin Heidegger (1. 1889) era tersebut adalah suatu masa yang ditandai oleh status manusia subjectum; pusat

\footnotetext{
${ }^{1}$ Schmidt menyatakan bahwa telah ada suatu monoteisme primitif sebelum manusia mulai menyembah banyak dewa. Pada awalnya mereka mengakui hanya ada satu Tuhan Tertinggi, yang telah menciptakan dunia dan menata urusan manusia dari kejauhan. Selanjutnya, di zaman kuno, Tuhan Tertinggi digantikan oleh tuhan-tuhan kuil pagan yang lebih menarik. Lihat Karen Amrstrong, Sejarah Tuban: Kisab Pencarian Tuban Yang Dilakukan Oleb Orang-orang Yabudi, Kristen, dan Islam Selama 4.000 Tabun, terj. Zainul Am (Bandung: Mizan, 2003), 27-28.

2 Menurut Descartes adalah keliru jika dikatakan bahwa kebenaran dapat dicapai dengan sesuatu yang sudah pasti dan tidak dapat diganggu gugat. Menurutnya,untuk mencapai kebenaran, seseorang harus melepaskan diri dari segala macam prasangka, termasuk prasangka yang berupa keyakinan dari dogma-dogma agama. Sebagai gantinya, ia harus menggunakan rasio dan pengetahuan berdasarkan fakta. Lihat Horald Titus, Persoalan-Persoalan Filsafat, terj. M. Rasjidi (Jakarta: Bulan Bintang, 1984), 78.
} 
dan ukuran yang berada (seinde). Puncak dari semua itu adalah "berubahnya" manusia menjadi 'bomo homoni deus' (menjadi Tuhan). ${ }^{3}$

Tidak dapat dielak jika corak antroposentris kemudian pada periode awal abad 19 melahirkan semangat otonomi dan independensi untuk mendeklarasikan kebebasan dari Tuhan. Inilah abad ketika Ludwig Feuerbach, Karl Mark, Charles Darwin, Friedrich Nietzsche, dan Sigmund Freud menyusun tafsiran filosofis dan ilmiah tentang realitas tanpa menyisahkan tempat buat Tuhan. Bahkan asumsi yang terbangun pada abad itu, sejumlah orang mulai merasakan bahwa sekirannya Tuhan belum mati, maka adalah tugas rasio manusia membunuhnya. ${ }^{4}$

Serbuan untuk membunuh Tuhan adalah upaya merobek ketergantungan yang tak pantas bagi martabat manusia terhadap Tuhan. Dengan membunuh Tuhan manusia menemukan kebebasannya. Reprensentasi tersebut secara tegas dimunculkan Friedrich Nietzsche (1844-1900) wakil dari eksistensialisme yang menyatakan bahwa dengan kematian Tuhan, manusia menjadi bebas dan terbuka kesempatan yang seluas-luasnya baginya untuk menentukan diri. $^{5}$ Namun demikian, kebebasan manusia ala eksistensialisme tidak selamanya berimplikasi kepada paham kematian Tuhan sebagai representasi ajarannya. Karena sebagian eksistensialis justru menentang kematian Tuhan atas nama kebebasan manusia juga.

Dengan demikian, hadirnya aliran eksistensialisme membawa pertarungan dua aliran di dalamnya, yaitu mereka yang mengakui eksistensi Tuhan dan mereka yang tidak mengakui eksistensi Tuhan. Keberadaan aliran eksistensialisme yang demikian menarik diangkat untuk mengetahui dialektika argumentasi eksistensialisme teistik maupun ateistik.

\section{Pemaknaan Teoretis Eksistensialisme}

Eksistensialisme muncul sebagai gerakan pemikiran yang menentang rezim rasionalisme dan intelektualisme yang mengakar kuat

\footnotetext{
3 Ignace Lepp, Ateisme Dewasa Ini, terj. Sayyid Umar \& Edy Sunaryo (Yogyakarta: Shalahuddin Press, 1985), 70.

${ }_{4}^{4}$ Amrstrong, Sejarah Tuban, 446.

5 St. Elmo Nauman, The New Dictionary of Existentialism (New York: The Philosophical Library, 1971), 67.
} 
dalam tradisi filsafat Barat. Hal tersebut dikarenakan filsafat Barat sebelumnya didominasi oleh anggapan bahwa kebenaran dapat disamakan dengan akal. "Eksistensialisme menolak bahwa kebenaran selamanya dapat disamakan dengan akal, sebuah tema sentral dalam pemikiran Plato, Kant, Hegel", demikian kata St. Elmo Nauman. ${ }^{6}$

Baik Plato, Kant, maupun Hegel sebagaimana disebut oleh Nauman di atas mempunyai kontribusi besar kepada doktrin esensialisme di dalam Abad Pencerahan. Reaksi dan protes eksistensialisme memang ditujukan kepada esensialisme Hegel, akan tetapi reaksi dan respons tersebut juga ditujukan terhadap aliran filsafat dan pemikiran yang mengarah kepada kolektivisme dan sistem.

Georg Wilhelm Friedrich Hegel (1770-1831) sendiri mambangun pemikirannya dengan melukiskan kenyataan sebagai dialektika Roh (Geist), Hegel mengabstraksi segala sesuatu menjadi sebuah sistem abstrak yang meremehkan manusia konkret atau individu. Yang merupakan kenyataan adalah ide abstrak atau Roh, dan bukan pengalaman individual. Dalam sistem abstrak itu bahkan kesadaran manusia konkret hanyalah sebuah momen dalam dialektika Roh. Bukan manusia yang sadar diri, melainkan Roh menyadari dirinya dalam manusia konkret itu. Oleh karena itu juga, Hegel memandang tinggi ide-ide kolektif, sebab semakin objektif sebuah ide semakin benar dan semakin real-lah ide itu. Dengan demikian yang makin benar adalah "kita", "ras", "zaman kita", "abad kita", "roh dunia", dan bukan "aku" atau "pikiranku".

Tesis Hegel di atas inilah yang melatarbelakangi dua mazhab eksistensialisme teistik dan ateistik untuk mendekonstruksi padangan Hegelianisme. Misalnya keberatan Søren Kierkegaard (1813-1855) terhadap Hegelianisme yang dapat kita sebut sebagai "kritik atas abstraksionis". Dengan sistem abstrak tersebut, Hegel dipandang Kierkegaard sudah mereduksi manusia menjadi "kawanan" (crowd) yang anonim. Kemampuan subjektif manusia untuk mengambil keputusan yang sangat pribadi dan berkomitmen dianggap tidak autentik dalam sistem itu, sebab yang real itu bukan individu melainkan Roh yang

\footnotetext{
${ }^{6}$ St. Elmo Nauman, The New Dictionary, 46.

${ }^{7}$ F. Budi Hardiman, Filsafat Modern dari Machiavelli sampai Nietzsche (Jakarta: Gramedia Pustaka Utama, 2004), 248.

${ }^{8}$ Hardiman, Filsafat Modern, 247.
} 
menjadi semakin sadar diri melalui individu itu. Bagi Kierkegaard, manusia secara individu memiliki kemampuan untuk membuat keputusan bebas secara personal dan menunaikan komitmen yang bermakna. Dengan jalan itu, menurut Kierkegaard, "manusia individual menerima martabatnya."

Sedang Karl Jespers (1883-1969), menolak sikap objektif seperti yang digambarkan oleh Hegel, Jesper tidak menghendaki ontologi yang berlaku umum. Akan tetapi "ada" Yang Melingkupi (das Umgreifende), ini merupakan kunci metafisikanya untuk melangkapi pemikirannya tentang transendensi. Yang dimaksud transendensi adalah Yang Melingkupi (das Umgreifende) bukanlah sesuatu yang kongkret, melainkan sesuatu yang tersembunyi. ${ }^{10}$

Bagi Martin Heidegger (1889-1976), bahwa filsafat yang sekian lama menggumuli realitas sudah lupa akan "adanya". Dalam segala yang ada dan nyata, yang paling dekat dan bisa diselidiki oleh filsafat adalah dirinya sendiri. Di dalam diri manusia timbullah pertanyaan tentang "ada" itu, karena ia makhluk yang ada dan mampu bertanya tentang itu, dan sekaligus akan menjawabnya. Dan itulah yang di dalam terminologi Heidegger disebut "Dasein", ini berarti jargon esensialisme dalam tesis Hegel "Apa yang nyata dapat dipikirkan, dan apa yang dapat dipikirkan adalah nyata", tidak dapat diterima oleh Heidegger."11 Lebih jauh negasi Heidegger terhadap Hegel adalah dengan menempatkan verstehen (mengerti, memahami) sebagai cara berada manusia yang dikaitkan dengan kebebasan manusia. ${ }^{12}$

Adapun Jean-Paul Sartre (1905-1980) seperti dua mata sisi uang yang berlawanan dengan Hegel. Sebagai eksistensialis, Sartre berminat pada pada inner experience, sedang Hegel atau Hegelianisme berminat pada objektive truth suatu sistem. Sartre berminat pada emosi-emosi, Hegel pada akal murni. Minat fenomenologis Sartre berbicara masalah

\footnotetext{
${ }^{9}$ Hardiman, Filsafat Modern, 247.

${ }^{10}$ Harun Hadiwijono, Sari Sejarah Filsafat Barat 2 (Yogyakarta: Kanisius, 2002), 173; lihat juga K. Bartens, Filsafat dalam Abad XX (Jakarta: Gramedia, 1988), 137.

11 Muzairi, Eksistensialisme Jean-Paul Sartre: Sumur Tanpa Dasar Kebebasan Manusia (Yogyakarta: Pustaka Pelajar, 2002), 40-41.

12 Verstehen ini bersangkut paut dengan manusia dan kemungkinan-kemungkinannya. Manusia hidup dalam suatu kesadaran akan "ada"-nya. Dilihat dari kesadaran akan ada-nya ini seluruh dunia penuh dengan kepentingan-kepentingan dan arti itu hanya dilihat dari kesatuannya dengan eksistensinya. Lihat, Hadiwijono, Sari Sejarah, 152.
} 
meaning, sedang obsesi rasionalis Hegel menghendaki integibility. Sartre memandang bahwa manusia merupakan bagian dari proses yang di dalamnya ia sedang berpartisipasi. Karena baginya, sejarah diindividualisasikan, masing-masing mempunyai kisahnya sendiri. Namun bagi Hegel, sejarah dimutlakkan dengan sejarah individuindividu yang ditelan dalam Roh manusia. ${ }^{13}$

Bentuk pemikiran dekonstruksi terhadap bangunan pemikiran esensialisme terutama esensialisme ala Hegel di atas, memunculkan term yang dikenal dengan eksistensialisme. Eksistensialisme sendiri merupakan pola dari akar kata "eksistensi" yang berasal dari kata eks yang berarti keluar dan sistensi yang diturunkan dari kata kerja sisto berarti berdiri, menempatkan. Oleh karena itu eksistensi berarti manusia berdiri sebagai diri sendiri yang sadar bahwa dirinya ada. ${ }^{14}$ Dengan keluar dari dirinya maka manusia secara individual menjadi sadar bahwa dia ada dan bebas. Kebalikan dari eksistensi adalah esensi. Esensi adalah yang menjadikan sesuatu benda apa adanya, atau sesuatu yang dimiliki secara umum oleh bermacam-macam benda. Esensi adalah umum untuk beberapa individu dan esensi dapat dibicarakan secara berarti walaupun tak ada contoh bendanya pada suatu waktu. ${ }^{15}$ Ciri umum dari eksistensialisme adalah eksistensi mendahului esensi. ${ }^{16}$

Selain ciri tersebut, ada beberapa ciri yang menjadi dasar bersama, antara lain:

1. Motif pokok yang disebut eksistensi adalah cara manusia berada. Hanya manusialah yang bereksistensi.

2. Bereksistensi harus diartikan secara dinamis. Bereksistensi berarti menciptakan dirinya secara aktif, bereksistensi berarti berbuat, menjadi, dan merencanakan. Setiap saat manusia menjadi lebih atau kurang dari keadaannya.

3. Di dalam filsafat eksistensialisme manusia dipandang terbuka. Manusia adalah realitas yang belum selesai, yang masih harus

${ }^{13}$ H. J. Blackham, Six Existentialist Thinkers (London: Routledge \& Kegan Paul, 1952), 41-44.

${ }^{14}$ Hadiwijono, Sari Sejarah, 148.

${ }^{15}$ Harold Titus, Persoalan-Persoalan Filsafat, terj. H.M. Rasjidi (Jakarta: Bulan Bintang, 1984), 384.

${ }^{16}$ Fuad Hasan, Berkenalan Dengan Eksistensialisme (Jakarta, Pustaka Jaya, 1989), 7. 
dibentuk. Pada hakikatnya manusia terikat kepada dunia sekitarnya, terlebih kepada sesama manusia.

4. Filsafat eksistensialime memberi tekanan kepada pangalaman yang kongkret dan eksistensial. Hanya saja, arti pengalaman itu yang berbeda-beda. ${ }^{17}$

Dari pengertian yang telah dipaparkan di atas dapat ditarik kesimpulan bahwa eksistensialisme adalah bentuk kebebasan manusia untuk membuat kehidupan dirinya sesuai dengan yang ia inginkan.

Pada umumnya, Søren Kierkegaard dinyana sebagai sumber pertama filsafat eksistensialisme. Søren Kierkegaard menyebut eksistensi dengan "diri autentik". Hanya "diri autentik" atau aku yang konkret yang bisa mengambil keputusan eksistensial. Sebagai eksistensi, aku ini bertindak. "Aku ini", dengan istilah Kierkegaard, "Aktor" kehidupan yang berani mengambil keputusan dasariah bagi arah hidupku sendiri, bukan "spectator" kehidupanku belaka. ${ }^{18}$ Dengan menggemakan kematian Tuhan, Friedrich Nietzsche menempatkan manusia menjadi bebas dan terbuka kesempatan yang seluas-luasnya baginya untuk menentukan diri. ${ }^{19}$ Martin Heidegger mengatakan bahwa eksistensi itu nampak pada ketiadaan dan ia sama sekali bukan hanya proyeksi manusia, melainkan sesungguhnya eksistensi manusia itu mendahului proyeksinya. Heidegger juga mengungkapkan bahwa "kita adalah eksistensi tanpa esensi". ${ }^{20}$ Selanjutnya, manusia yang tidak memiliki eksistensi menghadapi hidup yang semu. ${ }^{21}$

Jean-Paul Sartre adalah eksistensialis yang paling jelas menerangkan slogan existence precedes essence (eksistensi mendahului esensi) ini. Sartre menerangkan pengertian ini dengan analogi bahwa manusia tidak dapat disamakan dengan pisau kertas. Karena pisau kertas dibuat seseorang yang mempunyai konsep tentang pisau itu. Nampak sebelum jadi, pisau itu telah dikonsepsikan sebagai sesuatu benda yang mempunyai maksud tertentu dan dibuat dengan proses tertentu pula. Ini berarti esensi pisau telah ada. Menurutnya, manusia

\footnotetext{
${ }^{17}$ Hadiwijono, Sari Sejarah, 149.

${ }^{18}$ Hardiman, Filsafat Modern dari Machiavelli, 250.

${ }^{19}$ St. Elmo Nauman, The New Dictionary of, 67.

${ }^{20}$ Jean Wahl, A Short History of of Existentilism, terj. Forrest William and Stainley Maron (New York: The Philosophical Library, 1949), 14.

${ }^{21}$ Hadiwijono, Sari Sejarah, 156.
} 
ada tanpa didahului esensi. Ia ada kemudian bereksistensi membentuk esensinya. ${ }^{22}$

Bagi manusia, eksistensi adalah keterbukaan; berbeda dengan benda-benda lain yang keberadaanya sekaligus berarti esensinya. Hanya manusia saja yang memahami dan membentuk dirinya sendiri. Manusia mendefinisikan dirinya dengan tindakan-tindakannya. Karena Sartre berpandangan bahwa asas pertama bereksistensi adalah "manusia tidak lain kecuali dirinya yang ia buat sendiri." 23

Setiap eksistensialis, dengan penekanan yang berbeda, berbicara masalah kebebasan. Nietzsche memandang kebebasan sebagai jiwa yang agung. Baginya kebebasan adalah will to power. Kehendak berkuasa secara hahiki adalah seorang manusia yang kreatif; tetapi sang pencipta tidaklah mungkin diam dengan ditentukannya oleh hukum-hukum sebelumnya. Suatu tindakan kreatif yang unggul berisi norma-normanya sendiri, dan setiap penciptaan adalah suatu penciptaan norma-normabaru. ${ }^{24}$

Berbeda dengan Nietzsche, Karl Jespers menegaskan, bahwa kebebasan dan eksistensi adalah konsep-konsep yang bisa saling tukar. Sebagaimana diungkapkan oleh Jasper, "eksistensi ditampilkan dan direalisasikan dalam komunikasi; dan komunikasi itu hanya mungkin jika seandainya aku dan tetanggaku masing-masing tidak saling menjadikannya sebagai alatnya, akan bertemu dalam pengakuan timbal balik dengan menghormati kebebasan masing-masing." [Existence is revealed and realized in communication is only possible if I and my neighbour do not each make the orther his tool, but meet in mutual affirmation of our respective freedom.]. Apa yang dikembangkan Jasper tersebut dikenal dengan "Existential Communication". Di dalam komunikasi tersebut orang lain tidak dianggap sebagai objek, atau sebagai alat semata-mata, namun secara positif ditangkap sebagai pribadi yang berkembang dalam eksistensinya. Sehingga eksistensiku nampak dan riil berkat kehadiran orang lain. ${ }^{25}$

${ }^{22}$ Jean-Paul Sartre, Existentialism and Human Emotions, terj. Bernard Frectman (New York: The Philosophical Library, 1948), 13-15.

${ }^{23}$ Sartre, Existentialism, 13-15.

24 Walter A. Kaufmann, "Friederich Nietzsche" dalam The Encyclopedia of Philosophy (New York: Macmillan Publishing Co, Inc \& The Free Press, 1967), 510.

${ }^{25}$ Muzairi, Eksistensialisme, 58. 
Sedang Gabriel Marcel (1. 1889) menyatakan bahwa kebebasan manusia meliputi cinta kasih abadi. Apa yang dimaksudkan Marcel berhubungan dengan "ada" sebagaimana mata dengan cahaya. Marcel menekankan bahwa manusia menjumpai "yang ada", ini berarti dia menjadi "aku" karena menjumpai "engkau." Dengan demikian intersubjektivitas mendapat perhatian karena dia adalah makhluk bebas dan menjumpai "yang ada" karena cinta. ${ }^{26}$ Cinta kasih ini bersifat kreatif untuk menciptakan suatu dimensi eksistensial baru. Sebab di dalam cinta kasih inilah hubungan "aku-engkau" terjadi secara sempurna, dimana "aku" benar-benar menjadi "aku" dan orang lain benar-benar menjadi "engkau". Keduanya dipersatukan dalam satu kesatuan yang baru yang tidak dapat dirumuskan, tetapi hanya dapat dipahami di dalam kehadiran (presence), sebagai rahasia yang harus dipercaya. Realisasi yang istimewa dari kehadiran adalah dengan cinta. "aku" dan "engkau" di sini mencapai taraf "kita". Dalam cinta ini, "aku" mengikat diri dan tetap setia. ${ }^{27}$

Lain halnya dengan Søren Kierkegaard beranggapan bahwa hanya dengan kembali kepada kehidupan batinnya manusia akan menemukan kebebasannya. ${ }^{28}$ Apa yang diungkapkan Kierkegaard merupakan refleksi puncak petualangan pemikirannya yang berakhir pada Tuhan. Bagi Kierkegaard, Tuhan adalah tempat untuk menyerahkan segala kesejatian dan hidupnya. ${ }^{29}$ Dengan demikian, kehidupan batin manusia yang dituntun oleh Tuhan telah membawa pada sebuah kebebasan.

Adapun kebebasan bagi Heidegger hanya terjadi ketika kita memilih satu kemungkinan. Dalam situasi yang dibatasi oleh "nasib", segera manusia memilih satu kemungkinan, dirinya atau tidak memilih kemungkinan-kemungkinan yang lain, lalu mengadalah kebebasan. Kebebasan baru mengada dalam hal memilih satu kemungkinan, artinya menanggung bahwa kemungkinan-kemungkinan lain tidak dipilih dan tidak dapat dipilihnya. Situasi inilah yang oleh Heidegger disebut Schuld..$^{30}$

\footnotetext{
${ }^{26}$ Muzairi, Eksistensialisme, 41.

${ }^{27}$ Hadiwijono, Sari Sejarah, 176.

28 St. Elmo Nauman, The New Dictionary of, 56.

${ }^{29}$ Fuad Hasan, Berkenalan Dengan Ekesistensialisme, 42.

${ }^{30}$ Hadiwijono, Sari Sejarah, 156.
} 
Sedangkan kebebasan manusia menurut Sartre adalah mutlak. Tidak ada batas bagi kebebasan manusia. Dibalik kebebasan itu, manusia dituntut bertanggung jawab terhadap dirinya sendiri. Tanggung jawab itu meliputi kemanusiaan secara umum sebab dia dituntut memilih berbagai kemungkinan yang tersedia. Bagi Sartre, Tuhan tidak dapat dimintai tanggung jawab dan tidak bisa dijadikan tempat untuk menggantungkan tanggung jawab. Tuhan tidak terlibat dalam keputusan yang diambil manusia. Manusia adalah kebebasan dan hanya sebagai kebebasan ia bisa bertanggung jawab. ${ }^{31}$ Sebagai eksistensialis yang ateistik, Sartre sangat vokal menentang gagasan tentang Tuhan dan menggantinya dengan gagasan the absolute freedom. Sartre sering dan berulang-ulang menyebut Tuhan dalam tulisannya, tetapi tetap saja untuk ditolak kehadirannya ditengah-tengah kehidupan manusia. Di dalam karyanya Existentialism and Human Emotions, Sartre mempersoalkan Tuhan Sebagai pencipta God as Creator. ${ }^{32}$

\section{Eksistensi Tuhan: Teisme vis a vis Ateisme}

Dalam menyikapi eksistensi Tuhan, terdapat dua karakteristik eksistensialisme, yaitu ateisme dan teisme. Nama-nama seperti Nietzsche, Heidegger, Sartre, Albert Camus (1913-1960) adalah para tokoh eksistensialis ateistik, dan nama-nama seperti Kierkegaard, Karl Jasper, Gabril Marcel adalah diantara mereka yang mendukung eksistensialisme teistik. Menurut pengelompokan Sartre, yang termasuk

31 Bagi pemikiran Sartre yang mendasari kebebasan adalah rasa ketakutan dan kecemasan. Menurutnya, ketakutan memiliki objek, yaitu benda-benda dalam dunia. Adapun kecemasan menyangkut diri-sendiri dengan pernyataan bahwa eksistensi seseorang tergantung pada dirinya. Dalam ilustrasi yang digambarkan Sartre, "saya berdiri di tepi jurang yang terjal. Ketika menoleh ke bawah, saya merasa cemas. Kemudian saya bisa membayangkan apa yang terjadi pada diri saya bila saya menerjunkan diri kedalam jurang tersebut. Terjun atau mundur kebelakang adalah keputusan saya sendiri dan saya bertanggung jawab atas keputusan itu. Tidak ada yan memaksa saya untuk menyelamatkan hidup dan tidak ada yang menghalangi saya terjun ke dalam jurang. Saya yang bertanggung jawab atas perbuatan saya, yang mengakibatkan kecemasan. Kecemasan adalah kesadaran bahwa masa depan saya seluruhnya bergantung kepada saya." Menurutnya, kebebasan manusia tampak dalam kecemasan. Lihat Amsal Bahtiar, Filsafat Agama (Jakarta: Logos Wacana Ilmu, 1997), 152-153.

32 Sartre, Existentialism, 14. 
dalam kelompok teisme adalah Karl Jaspers dan Gabriel Marcel dan yang ateisme adalah dia sendiri dan para eksistensialis Prancis. ${ }^{33}$

Ciri yang menonjol untuk membedakan kedua eksistensialisme adalah bahwa yang ateisme menolak Tuhan demi kebebasan manusia, sedangkan teisme justru dengan menerima Tuhan manusia mendapatkan kebebasannya. Kedua-duanya sama-sama menekankan pentingnya individualitas dan kebebasan dan juga memandang manusia sebagai realitas terbuka dan tidak pernah selesai. Argumen eksistensialisme ateistik, apabila eksistensi Tuhan diterima berarti eksistensi manusia menjadi semu, karena kebebasannya dibatasi oleh kemahakuasaan Tuhan. Eksistensialisme teistik berpendapat, manusia mengatasi temporalnya yang menjadi ciri eksistensi dengan menjadikan Tuhan sebagai masa depannya.

Dari ciri tersebut nampak jelas bahwa kemunculan dua aliran tersebut sebenarnya dipicu oleh permasalahan eksistensi Tuhan. Bagaimanapun juga mereka lahir di bawah kultur Barat yang berakar kuat pada rezim esensialisme dan instutionalisme. Dari rezim seperti itu, lahir lembaga-lembaga Kristen dan pandangan-pandangan Kristen esensialistik. Gereja muncul sebagai institusi otoriter yang tidak hanya mendeterminasi para penganutnya, tapi kadang-kadang juga mendikte perkembangan kultural. ${ }^{34}$ Bentuk seperti ini tidak jauh beda dengan Islam. Jika Barat mengatakan "Tuhan telah mati." Maka Islam mengatakan "pemikiran kenabian telah mati" atau "Nabi telah mati". Hal ini tidak lepas dari pernyataan ilmu pengetahuan datangnya dari Nabi. Semakin jauh suatu masa dari Nabi maka ilmu pengetahuan akan semakin merosot; pada gilirannya merosot pula kebudayaan dan peradaban. $^{35}$

Mendapati Kebudayaan Barat-Kristen yang demikian, Friedrich Nietzcshe dalam salah satu karyanya membuat ilustrasi orang gila yang mondar-mandir di pasar sambil berujar, "Tidakkah kita mendengar kesibukan para penggali kubur yang sedang mengubur Tuhan? Apakah kita tidak mencium bau bangkai Tuhan? Bahkan Tuhan telah menjadi

\footnotetext{
33 Sartre, Existentialism, 13.

34 Friedrich Nietzshe, The Joyful Wisdom, terj. Thomas Common (London: NtN Voulis, t.th.), 50 .

35 Abdurrahman Badawi, Sejarah Ateis Islam: Penyelewengan, Penyimpangan, Kemapanan, terj. Khoiron Nahdiyyin (Yogyakarta: LKiS, 2003), 1-4.
} 
busuk. Tuhan mati. Tuhan akan tetap mati, dan kita telah membunuhnya." 36 Ilustrasi Nietzcshe yang memaklumatkan kematian Tuhan ini tentu bukan dalam arti yang sebenarnya, melainkan simbol kegelisahan terhadap bentuk kepercayaan nilai-nilai universal-absolut agama yang telah menyetubuhi kebebasan sebagai kreativitas individu menjadi objek yang tak berdaya. Potret historis menunjukkan semenjak tahun 1546 agama Kristen (Katolik) dengan lembaga gerejanya telah menjelma menjadi institusi otoriter yang paling berkuasa dalam mendeterminasi penganutnya dengan nilai-nilai universal-absolut agama. Bahkan melalui otoritas ini dimanfaatkan untuk mengintervensi perkembangan budaya. Bukti intervensi agama ke dalam gerak budaya tergambar dalam ungkapan Nietzsche, "apa yang ditolak Kristen adalah fakta budaya manusia yang besar." ${ }^{\text {'7 }}$

Kritik tajamnya terhadap agamanya yang tersebar dalam berbagai karyanya yang puncaknya pada buku Anti Christ membuatnya dikenal sebagai seorang ateis yang paling ekstrem. Kematian Tuhan ditegaskannya karena ia harus memilih satu di antara dua: Tuhan atau manusia. Ungkapan tentang tersebut bukanlah suatu ratapan, melainkan hanya sekedar pilihan. Tuhan hidup, manusia mati, atau sebaliknya, manusia hidup dan Tuhan harus mati. Keduanya tidak mungkin hidup bersama. ${ }^{38}$

Apa yang dilakukan Nietzsche itu menginspirasi Sartre dengan menentang gagasan Tuhan dan menggantinya dengan gagasan the absolute freedom. Di dalam karyanya Existentialism and Human Emotions, Sartre mempersoalkan Tuhan Sebagai pencipta God as Creator. ${ }^{39}$ Tuhan mencipta berdasarkan ide tertentu tentang realitas yang akan diciptakan. Dengan demikian, Tuhan mengetahui esensi benda-benda, termasuk manusia yang telah diciptakan-Nya itu. Proses dan cara Tuhan mencipta ini, ia analogikan dengan seorang ahli pembuat pisau pemotong kertas (paper cutter), yang sebelumnya telah didahului oleh suatu gagasan tentang kepisau-kertasan. Sebagaimana Sartre mengungkapkan, "ketika kita memahami Tuhan sebagai pencipta, dia

\footnotetext{
${ }^{36}$ Nietzcshe, The Joyful Wisdom, 167.

${ }^{37}$ Nietzcshe, The Joyful Wisdom, 50.

38 Choirul Arifin, Kehendak untuk Berkuasa Friedrich Nietssche (Jakarta: Airlangga, 1987), 7 dan 11.

${ }^{39}$ Sartre, Existentialism, 14.
} 
secara umum dianggap sebagai semacam seorang yang sangat ahli." 40 Dengan berpijak Tuhan sebagai pencipta, lantas Sarter berujar, "kalau Tuhan maha tahu, tidak ada yang tinggal bagiku untuk aku temukan; aku selalu menemukan hal-hal yang sudah diketahui." ${ }^{\prime 1}$ Hal ini berarti bahwa tidak ada keaslian tindakan manusia. Seorang manusia tidak dapat mengubah apa yang telah ditentukan Tuhan. Atas dasar tersebut para eksistensialis ateistik memberontak intervensi Tuhan yang pada akhirnya menghilangkan eksistensi Tuhan dan menjadikan manusia sendiri untuk memiliki kebebasannya yang pada akhirnya memunculkan aktivitas kreatif manusia.

Tidak ketinggalan, eksistensialisme teistik juga menolak esensialis Kristen yang dikemas dalam konsep-konsep logis, karena cenderung mengabaikan hubungan personal manusia dengan Tuhannya. Tuhan tidak mereka pahami sebagai esensi, tetapi sebagai individu; bukan dengan cara impersonal tetapi personal. Di bawah bayang-bayang Kierkegaard, Marcel dan Jaspers berpendirian sama bahwa absolutisme Hegelian hanya menampilkan Kristen dalam suatu sistem tertutup dan membuat nonsen hubungan manusia dengan Tuhannya. ${ }^{42}$

Dalam pandangan eksistensialis teistik, Tuhan tidak dipahami sebagai suatu diri yang berdiri "di belakang" manusia, tetapi ia menjadi arah proyeksi dari eksistensi manusia. Dalam kebebasannya, manusia tidak bisa memenuhi tuntutan etisnya sendiri. Sebagaimana digambarkan melalui momen-momen krisis seperti nampak dalam pandangan Kierkegaard, yakni tiga tahap kehidupan; tahap pertama adalah estetis, tahap ini dimaksudkan bahwa individu yang berada pada tahap ini, diombang-ambingkan oleh dorongan indrawi dan emosiemosinya. Semboyan hidupnya adalah "kenikmatan segera", sedangkan hari esok dipikir besok. Oleh karena itu patokan-patokan moral tidak cocok untuk tahap ini, sebab akan menghambat pemuasan hasrat individu. Individu juga tidak memilki asas-asas kokoh sehingga dia dengan mudah terpikat dari orang yang satu ke orang yang lain, atau dari benda satu ke benda yang lain. Ketakutan pokoknya adalah rasa

\footnotetext{
40 Sartre, Existentialism, 14.

${ }^{41}$ Nico Syukur Dister OFM, Filsafat Kebebasan (Yogyakarta: Penerbit Kanisius, 1993), 29.

42 F.C. Copleston, S.J., Existentialism and Modern Man (London: Blackfriars Publication, 1968), 10.
} 
tidak enak dan kebosanan. Meski memiliki ciri-ciri rendah semacam itu, tahap ini juga tahap eksistensial. Artinya orang bisa dengan bebas memilih untuk hidup dan secara konsisten hidup sebagai manusia estetis. Menurut Kierkegaard, kalau dengan bebas dipilih oleh manusia estetis, rasa putus asa itu akan membawanya ke sebuah kebebasan. Dengan kata lain, dia akan menghadapi tawaran untuk hidup menurut eksistensi yang baru, yaitu tahap etis. ${ }^{43}$

Tahap kedua adalah etis, untuk sampai pada tahap etis, individu itu harus membuat pilihan bebas, sebuah "lompatan eksistensial". Jadi, tahap ini bukan tahap yang niscaya mutlak atau otomatis. Pada tahap ini, individu dapat menguasai dirinya dan mengenali dirinya. Dia menyesuaikan tindakan-tindakannya dengan patokan-patokan moral universal. Baginya ada distansi yang jelas antara baik dan buruk. Menurut Kierkegaard, manusia etis masih terkungkung pada dirinya sendiri. Jadi, meskipun dia berusaha mancapai asas-asas moral universal, dia masih bersikap imanen, yaitu mengandalkan kekuatan rasionanya belaka. Menurut Kierkegaard, manusia etis tidak memahami bahwa dasar-dasar eksistensinya serba terbatas. Dia tidak menjumpai "Paradoks Absolut". Tetapi kalau hidupnya semakin dalam, dia akan menjumpai Paradoks Absolut itu, dan dia ditantang untuk melompat ke cara eksistensi yang baru, tahap religius. ${ }^{44}$

Tahap ketiga adalah religius. Tahap religius ini ditandai dengan pengakuan individu akan Allah, dan kesadarannya sebagai pendosa yang membutuhkan pengampunan Allah. Pada tahap ini individu membuat komitmen personal dan melakukan apa yang disebutnya "lompatan iman". Lompatan ini bersifat non-rasional dan biasa kita sebut pertobatan. Tokoh yang memodelkan tahap ini adalah Abraham. Tokoh dan kitab suci ini dengan keputusan bebasnya mengorbankan putra tunggalnya, Iskak, karena beriman kepada Allah yang menghendaki pengorbanan itu. ${ }^{45}$

Sementara dalam pandangan Jaspers yang bersumber pada taransenden atau Yang Melingkupi (das Umgreifende) menempatkan kehidupan manusia terarah kepada Allah (esse ad Deum). Tentang yang transenden atau Allah sebetulnya hanya dapat kita berpikir dan

\footnotetext{
43 Hardiman, Filsafat Modern, 252-253.

44 Hardiman, Filsafat Modern, 253.

${ }^{45}$ Hardiman, Filsafat Modern, 253-254.
} 
berbicara dengan memanfaatkan simbol-simbol (Chiffren) yang disajikan oleh kesenian dan mitologi. Melalui jalan ini alam bisa dibaca dan ditafsirkan sebagai jejak Allah (vestigial Dei). Dengan begitu eksistensialisme Jaspers mendapat sifat religius. Itu tidak berarti bahwa Jaspers mempunyai suatu pandangan Kristiani seperti Kierkegaard, namun ia tetap percaya pada Tuhan. Filsafatnya menjauhkan diri dari setiap macam scientisme secara rasional, tapi tanpa menjadi anti-ilmiah atau irasional. Filsafat tidak dapat memberikan suatu pembuktian empiris sebagaimana diberikan dalam pengetahuan ilmiah tentang benda-benda berhingga, namun ia dapat mencapai juga Gewissheit von $W$ abrheit, kepastian tentang kebenaran. Tetapi kepastian ini tidak langsung didasarkan atas suatu bukti ilmiah atau suatu penalaran rasional, namun mempunyai juga motif-motifnya dan baru boleh disebut kepastian karena bersekutu dengan pengetahuan (im Bund emit dem Wissen). Kepercayaan ini sebetulnya sama dengan kehidupan kita sendiri: aktus (tindakan) dari eksistensi kita di mana kita mulai menyadari transendensi menurut kenyataannya. Rumusan kesayangan Jaspers untuk mengungkap kepercayaan filosofis ini akhirnya berbunyi: "Kepercayaan adalah hidup yang bersumber pada Yang Melingkupi (das Umgreifende), artinya membiarkan kehidupannya dituntun dan dipenuhi oleh Yang Melingkupi". ${ }^{46}$

Sedangkan dalam eksistensialisme Marcel, kemandirian individu yakni "aku" yang tidak henti pada a self en-closed unit, suatu unit diri yang tertutup, tetapi sesuatu unit diri yang "terbuka" untuk yang lain yang dikemas oleh cinta kasih abadi. Yang lain itu merupakan objek baginya, jadi sebagai "dia", mungkin juga merupakan yang ada bagi "aku". Aku ini membentuk diri terutama dalam hubungan "aku-engkau" ini. Dalam hubungan ini kesetiaanlah yang menentukan segala-galanya. Setia itu hanya mungkin karena orang merupakan bagian "engkau" yang mutlak (Tuhan). Kesetiaan yang menciptakan "aku" ini pada akhirnya berdasarkan atas partisipasi manusia kepada Allah. Di dalam cinta kasih ada kesetiaan dan kepastian, bahwa ada Engkau yang tidak dapat mati. Harapan itulah yang menerobos kematian. Adanya harapan menunjukkan, bahwa kemenangan dalam kematian adalah semu. Ajaran tentang harapan ini menjadi puncak ajaran Marcel. Harapan ini

46 P.A. van der Weij, Filsuf-Filsuf Besar Tentang Manusia, terj. K. Bertens (Jakarta: Penerbit PT Gramedia Pustaka Utama, 1991), 144-148. 
menunjuk adanya Engkau Yang Tertinggi (Toi Supreme), yang tidak dapat dijadikan objek manusia. ${ }^{47}$ Melalui relasi dengan orang lain, dari eksistensi Marcel dapat menghantarkan kita kepada kehadiran dari "Yang Lain" atau Tuhan. Di sinilah maka kepercayaan, iman, dan harapan tida $\mathrm{k}$ memerlukan pembuktian sistematis maupun logika empiris.

Sampai di sini sintesis antara eksistensialisme teistik dan ateistik adalah bentuk reaksi dan respons terhadap filsafat esensialisme Hegel dan rasionalisme dalam filsafat Barat Modern dengan menekankan pentingnya eksistensi manusia kepada kebebasan. Manusia adalah diri yang sadar, konkret dan bebas. Sedangkan antitesis kedua eksistensialisme tersebut adalah problem eksistensi Tuhan. Para eksistensialis yang ateistik menolak eksistensi Tuhan yang pada gilirannya merampas kebebasan manusia. Para eksistensialis teistik justru menerima Tuhan dan menganggapnya tidak merampas kebebasan manusia perorangan karena Tuhan dipahami secara individual, bukan sebagai suatu sistem diri yang tertutup.

\section{Refleksi Kritis terhadap Mazhab Eksistensialisme}

Membaca pemikiran eksistensialisme ateistik terutama Nietzsche dan Sartre tentang Tuhan dan alasan-alasan mereka menolak keberadaan Tuhan dapat disimpulkan bahwa kegiatan Tuhan meniadakan kepadatan eksistensi manusia. Sebaliknya, kepadatan eksistensi manusia akan tumbuh jika Tuhan dibunuh. Dengan kata lain, para eksistensialis yang atestik memberontak intervensi Tuhan sekaligus menghilangkan eksistensi-Nya dengan menjadikan manusia untuk memiliki kebebasannya yang pada gilirannya memunculkan aktivitas kreatif manusia. Menurut Nico Syukur Dister, jalan pikiran seperti inilah yang merupakan kesulitan yang mereka hadapi, disebabkan oleh semacam antropomorfisme dalam anggapan mereka tentang Tuhan. ${ }^{48}$ Visi antropomorfisme tampak begitu jelas. Tuhan disamakan dengan tukang paper-cutter. Jika Tuhan adalah seperti yang digambarkan Sartre yaitu disamakan seperti tukang paper-cutter maka bisa dimaklumi bahwa eksistensi Tuhan seperti gambaran itu akan meniadakan otentisitas dan kebebasan manusia.

${ }^{47}$ Hadiwijono, Sari Sejarah, 176-177.

${ }^{48}$ Dister OFM, Filsafat Kebebasan, 28-29. 
Pada sisi yang lain, sebagaimana dipenjelasan terdahulu bahwa kemunculan eksistensialisme merupakan reaksi terhadap doktrin esensialisme dan pemikiran apapun yang mengarah kepada kolektivisme maupun sistem, dengan mengkonstruksi kemampuan subjektif manusia untuk mengambil keputusan individualis yang kreatif. Sayangnya, individualisme yang dikonstruk telah menjadi bentuk keberhalaan baru, sebab bersikap individualistis justru menjadi satusatunya tujuan. Bagaimanapun semua individualitas sejati berasal dari Tuhan. Bagi Karen Amrstrong, seorang yang jenius bisa jadi berbahaya jika secara mutlak dibiarkan lepas kendali. Manusia Super yang menganggap diri sendiri sebagai Tuhan seperti yang diketengahkan Nietzsche merupakan proyek yang mengerikan-orang membutuhkan aturan yang melampaui pengetahuan dan dugaanya. ${ }^{49}$

Sebaliknya, proyek yang demikian, tidak kita temukan jika kita memahami seperti apa yang ditawarkan oleh Muhammad Iqbal (18771938) seorang filsuf Muslim modern yang justru menjadi pengagum Nietzsche..$^{50}$ Menurut Iqbal, seluruh alam mewakili Yang Mutlak yang merupakan bentuk tertinggi individuasi yang oleh manusia disebut sebagai "Tuhan". Untuk mewujudkan keunikan mereka, semua manusia harus menjadi semakin menyerupai Tuhan. Ini berarti setiap manusia harus menjadi lebih individual, lebih kreatif dan mesti mengungkapkan kreativitasnya dalam bentuk perbuatan. ${ }^{51}$ Menunjukkan konsistensi pernyataannya, dalam salah satu sajaknya, Iqbal melukiskan penempatan eksistensial antara kebebasan manusia dan Tuhan sebagai wujud pencipta:

Kau ciptakan malam dan aku buat lampu

Kau ciptakan lempung dan aku ciptakan cawan

Kau ciptakan padang pasir, gunung dan rimba

Aku membuat kebun, taman dan butan buatan

Akulah yang mengubah racun menjadi obat penawar

Kebesaran manusia terletak dalam daya ciptanya

Bulan bintang hanya mengulang-ulangi

\footnotetext{
49 Amrstrong, Sejarah Tuban, 469

50 Amrstrong, Sejarab Tuhan, 468.

51 Amrstrong, Sejarah Tuhan, 468.
} 


\section{Kewajiban yang ditetapkean atasnya. ${ }^{52}$}

Dari lukisan sajak tersebut, otentisitas individu manusia diberikan dan diakui oleh Tuhan, tegasnya manusia dengan aktivitas bebas dan kreatifnya, yang merupakan anugerah Tuhan, bersaksi dan mengakui eksistensi-Nya, yang dengan kehendak bebas-Nya menciptakan keaslian eksistensi individu manusia.

Sementara itu, Kierkegaard yang mewakili eksistensialis teistik menempatkan kehidupan duniawi sebagai kehidupan etis, yaitu pemilikan sadar dari diri yang bebas. Meskipun demikian, dalam eksiastensialisme Kierkegaard, terdapat konflik antara tahap estetika dan tahap religius, yaitu kekuatan dan kegelisahan dalam realitas etis diri manusia dan untuk mengatasinya manusia melompat ke dalam panggilan kewajiban tertinggi, ke dalam diri Tuhan, melalui iman. Individualitas Kierkegaard terserap ke dalam diri Kristus. Padahal sayogyanya, antara tahap etis dan tahap religuis tidak ada konflik, maupun apa yang disebut Kierkegaard dengan momen-momen krisis setidaknya tidak ada, tetapi sebaliknya penemuan Tuhan manusia adalah wujud dari aktivitas dan kreativitasnya dan semakin menegaskan individualitas, kebebasannya dan immoralitasnya.

\section{Catatan Akhir}

Filsafat eksistensialisme menaruh perhatian yang besar terhadap terhadap nasib manusia sebagai individu yang kurang mendapatkan perhatian di awal abad modern. Kemunculan eksistensialisme pada gilirannya merambat ke dalam polemik penemuan manusia akan Tuhannya. Adapun wacana ketuhanan dalam dataran eksistensialisme terdapat dua konsepsi yang berdialektika, yakni eksistensialisme ateistik dan eksistensialisme teistik.

Menjadi penting bagi kita yang beragama untuk banyak menyelami pemikiran-pemikiran para eksistensialis khususnya yang ateistik untuk mengetahui argumentasi-argumentasi mereka dan kemudian menjawabnya dengan argumentasi-argumentasi pula. Sampai di sini dapat diketengahkan, adalah misi Islam untuk menyelamatkan individualisme sejati (Manusia Sejati) dari penyimpangan eksistensialisme ateistik. Gubahan tentang Manusia Sejati (Sempurna)

${ }^{52}$ Luce Claude Maitre, Pengantar ke Pemikiran Iqbal, terj. Djohan Effendi (Bandung: Mizan, 1989), 32. 
dalam Islam memiliki figur ideal di dalam kajian sufisme. Berbeda dengan Manusia Super ciptaan Nietzsche yang memandang dirinya sebagai Tuhan dan meremehkan manusia yang lain, Manusia Sempurna dicirikan oleh ketundukan totalnya terhadap Yang Mutlak dan pemihakannya terhadap orang banyak. Yang demikian itu akhirnya setiap orang mencapai kesempurnaan individualitasnya di dalam Tuhan.

\section{Daftar Pustaka}

Amrstrong, Karen. Sejarab Tuban: Kisab Pencarian Tuban Yang Dilakukan

Oleh Orang-orang Yabudi, Kristen, dan Islam Selama 4.000 Tahun, terj. Zainul Am. Bandung: Mizan, 2003.

Arifin, Choirul. Kehendak untuk Berkuasa Friedrich Nietzsche. Jakarta: Airlangga, 1987.

Badawi, Abdurrahman. Sejarah Ateis Islam: Penyelewengan, Penyimpangan, Kemapanan, terj. Khoiron Nahdiyyin. Yogyakarta: LKiS, 2003.

Bahtiar, Amsal. Filsafat Agama. Jakarta: Logos Wacana Ilmu, 1997. Bartens, K. Filsafat dalam Abad XX. Jakarta: Gramedia, 1988.

Blackham, H. J. Six Existentialist Thinkers. London: Routledge \& Kegan Paul, 1952.

Claude Maitre, Luce. Pengantar ke Pemikiran Iqbal, terj. Djohan Effendi. Bandung: Mizan, 1989.

Copleston, S.J., F.C. Existentialism and Modern Man. London: Blackfriars Publication, 1968.

Hadiwijono, Harun. Sari Sejarah Filsafat Barat 2. Yogyakarta: Kanisius: 2002.

Hardiman, F. Budi. Filsafat Modern dari Machiavelli sampai Nietssche. Jakarta: Gramedia Pustaka Utama, 2004.

Kaufmann, Walter A. "Friederich Nietzsche" dalam The Encyclopedia of Philosophy. New York: Macmillan Publishing Co, Inc \& The Free Press, 1967.

Lepp, Ignace. Ateisme Dewasa Ini, terj. Sayyid Umar \& Edy Sunaryo. Yogyakarta: Shalahuddin Press, 1985.

Muzairi. Eksistensialisme Jean-Paul Sartre: Sumur Tanpa Dasar Kebebasan Manusia. Yogyakarta: Pustaka Pelajar, 2002.

Nauman, St. Elmo. The New Dictionary of Existentialism. New York: The Philosophical Library, 1971. 
Nietzcshe, Friedrich. The Joyful Wisdom, terj. Thomas Common London: NtN Voulis, t.th.

Sartre, Jean-Paul. Existentialism and Human Emotions, terj. Bernard Frectman. New York: The Philosophical Library, 1948.

Syukur Dister OFM, Nico. Filsafat Kebebasan. Yogyakarta: Penerbit Kanisius, 1993.

Titus, Harold. Persoalan-Persoalan Filsafat, terj. H.M. Rasjidi. Jakarta: Bulan Bintang, 1984.

Wahl, Jean. A Short History of Existentilism, terj. Forrest William and Stainley Maron. New York: The Philosophical Library, 1949.

Weij, P.A. van der. Filsuf-Filsuf Besar Tentang Manusia, terj. K. Bertens. Jakarta: Penerbit PT Gramedia Pustaka Utama, 1991. 